\title{
Anaerobic Degradation of Acetone and Higher Ketones via Carboxylation by Newly Isolated Denitrifying Bacteria
}

\author{
By HARALD PLATEN* AND BERNHARD SCHINK \\ Lehrstuhl Mikrobiologie I, Eberhard-Karls-Universität, Auf der Morgenstelle 28, \\ D-7400 Tübingen, Federal Republic of Germany
}

(Received 26 July 1988; revised 14 November 1988; accepted 12 December 1988)

Five strains of Gram-negative denitrifying bacteria that used various ketones as sole carbon and energy sources were isolated from activated sludge from a municipal sewage plant. Three strains are related to the genus $P$ seudomonas; two non-motile species have not yet been affiliated. All strains grew well with ketones and fatty acids $\left(C_{2}\right.$ to $\left.C_{7}\right)$, but sugars were seldom utilized. The physiology of anaerobic acetone degradation was studied with strain $\mathrm{BunN}$, which was originally enriched with butanone. Bicarbonate was essential for growth with acetone under anaerobic and aerobic conditions, but not if acetate or 3-hydroxybutyrate were used as substrates. An apparent $K_{\mathrm{s}}$ value of $5.6 \mathrm{~mm}$-bicarbonate was determined for growth with acetone in batch culture. The molar growth yield was $24.8-29.8 \mathrm{~g}$ dry cell matter (mol acetone consumed $)^{-1}$, with nitrate as the electron acceptor in batch culture; it varied slightly with the extent of poly- $\beta$-hydroxybutyric acid (PHB) formation. During growth with acetone, ${ }^{14} \mathrm{CO}_{2}$ was incorporated mainly into the $\mathrm{C}-1$ atom of the monomers of the storage polymer PHB. With 3hydroxybutyrate as substrate, ${ }^{14} \mathrm{CO}_{2}$ incorporation into $\mathrm{PHB}$ was negligible. The results provide evidence that acetone is channelled into the intermediary metabolism of this strain via carboxylation to acetoacetate.

\section{INTRODUCTION}

Acetone enters natural environments from various sources. In anoxic environments, it can be formed by bacterial fermentations (Schardinger, 1905; Northrop et al., 1919; Davies \& Stephenson, 1941; Widdel, 1986) and it is also excreted by mammals during starvation or diabetes (Widmark, 1920). Bringmann \& $\operatorname{Kuhn}(1977,1978)$ reported that acetone has a weakly toxic effect on bacteria (MIC 530-1700 $\mathrm{mg} \mathrm{l}^{-1}$ ) and green algae (MIC $7500 \mathrm{mg} \mathrm{l}^{-1}$ ) in comparison to other water pollutants. In aerobic waste water treatment, acetone is regarded as easily degradable (Roth, 1988).

Mechanisms of acetone degradation have been studied by several authors. In rats, two pathways of acetone degradation were found involving an initial oxygenation to acetol (for review, see Landau \& Brunengraber, 1987) or a biotin-dependent carboxylation to acetoacetate (Plaut \& Lardy, 1950). In aerobic bacteria, acetone is also degraded via oxygenation (Levine \& Krampitz, 1952; Lukins \& Foster, 1963; Vestal \& Perry, 1969; Taylor et al., 1980). In the absence of molecular oxygen, acetone is completely degraded to methane (Mazé, 1915). Evidence was provided recently that a carboxylation reaction plays a key role in this degradation (Platen \& Schink, 1987). Also the denitrifying bacterium Thiosphaera pantotropha can degrade acetone (Robertson \& Kuenen, 1983) and a carboxylation reaction is involved in this degradative process as well (Bonnet-Smits et al., 1988). The same appears to be true for cell carbon synthesis from acetone by a non-oxygenic photosynthetic Rhodocyclus gelatinosus

Abbreviation: PHB, poly- $\beta$-hydroxybutyric acid.

0001-5036 C 1989 SGM 
(Rhodopseudomonas gelatinosa) strain (Siegel, 1950). A different mechanism of anaerobic acetone degradation has been suggested which involves hydration or phosphorylation to pronanediol or propanediol phosphate as intermediates (Rudney, 1954).

Here we describe newly isolated strains of denitrifying bacteria which degrade ketones in the absence of molecular oxygen. Evidence is provided that anaerobic growth with acetone depends on carbon dioxide, and that its degradation involves a carboxylation reaction as a primary step.

\section{METHODS}

Source of denitrifying ketone-degrading bacteria. The bacteria were enriched from activated sludge taken from the municipal sewage plant in Marburg, FRG.

Media. The carbonate-buffered mineral salts medium (modified after Widdel \& Pfennig, 1981) used for enrichment cultures contained (in mmol 1-1): $\mathrm{KH}_{2} \mathrm{PO}_{4}, 1.5 ; \mathrm{NH}_{4} \mathrm{Cl}, 3 \cdot 7 ; \mathrm{Na}_{2} \mathrm{SO}_{4} \cdot 10 \mathrm{H}_{2} \mathrm{O}, 0.5 ; \mathrm{NaCl}, 17 \cdot 0$; $\mathrm{MgCl}_{2} .6 \mathrm{H}_{2} \mathrm{O}, 2 \cdot 0 ; \mathrm{KCl}, 6 \cdot 7 ; \mathrm{CaCl}_{2} .2 \mathrm{H}_{2} \mathrm{O}, 1 \cdot 0 . \mathrm{NaHCO}_{3}\left(30 \mathrm{mll}^{-1}\right.$ of a $1 \mathrm{M}$ stock solution), trace element solution SL 10 (Widdel et al., $1983 ; 1 \mathrm{ml}^{-1}$ ), and vitamin solution (10-fold concentrated, after Widdel \& Pfennig, 1981;0.5 $\mathrm{ml} \mathrm{1^{-1 }}$ ) were added after sterilization. The $\mathrm{pH}$ was adjusted to $7 \cdot 2-7 \cdot 4$ with $\mathrm{HCl}$. Rubber-stoppered serum bottles were half-filled with medium under a $\mathrm{N}_{2} / \mathrm{CO}_{2}(90: 10, \mathrm{v} / \mathrm{v})$ gas atmosphere.

The phosphate-buffered mineral salts medium contained (in mmol 1-1): $\mathrm{NH}_{4} \mathrm{Cl}, 2 \cdot 0 ; \mathrm{Na}_{2} \mathrm{SO}_{4} \cdot 10 \mathrm{H}_{2} \mathrm{O}, 0.5$; $\mathrm{MgCl}_{2} .6 \mathrm{H}_{2} \mathrm{O}, 0.5 ; \mathrm{CaCl}_{2} .2 \mathrm{H}_{2} \mathrm{O}, 0.1$; potassium phosphate buffer $(\mathrm{pH} 7 \cdot 0), 3 \cdot 0$; sodium phosphate buffer ( $\mathrm{pH}$ 7.0), 20.0; and trace element solution SL $10\left(1 \mathrm{ml} \mathrm{l}^{-1}\right)$. The phosphate buffers (stock solution $\left.0.5 \mathrm{M}\right)$ and trace elements were added after autoclaving. To avoid contamination with carbon dioxide, the medium was cooled under an atmosphere of $\mathrm{N}_{2}$ or $\mathrm{Ar}$ gas. Further additions (e.g. sodium nitrate, carbon sources) were made from 0.5$1.0 \mathrm{M}$ stock solutions. Media were bottled in Hungate tubes or serum bottles under $\mathrm{N}_{2}$ or $\mathrm{Ar}$ gas atmosphere.

TS-agar was prepared from Bacto tryptic soy broth $\left(30 \mathrm{~g}^{-1}\right.$, Difco) and agar $\left(15 \mathrm{~g}^{-1}\right)$.

Microbiological techniques. Pure cultures were obtained with the agar shake dilution technique (Pfennig \& Trüper, 1981) using carbonate-buffered medium. Strain BunN was cultivated in Hungate tubes ( $17.5 \mathrm{ml}$ volume) and infusion bottles of various volumes $(100-1000 \mathrm{ml})$. Growth was determined by measuring turbidity in a Spectronic 20 photometer (Milton Roy Company, USA) at $440 \mathrm{~nm}$ in Hungate tubes. Standard identification techniques (oxidase, catalase, Gram-type, negative staining with Indian ink) were carried out as described by Süssmuth et al. (1987). Wet mounts for phase contrast photomicrographs were prepared after Pfennig \& Wagener (1986). Tests for nitrogen fixation were carried out in liquid phosphate-buffered medium with $10 \mathrm{mM}-3-$ hydroxybutyrate and without ammonia or nitrate salts, in either non-shaken or slightly shaken culture (70 r.p.m. in Erlenmeyer flasks without baffles). Autotrophic growth was tested in phosphate-buffered medium supplemented with $20 \mathrm{~mm}$-sodium bicarbonate in $500 \mathrm{ml}$ infusion bottles with $50 \mathrm{ml}$ medium and a $\mathrm{H}_{2} / \mathrm{O}_{2}(80: 20$, v/v) gas atmosphere or $20 \mathrm{~mm}$-sodium nitrate under $100 \%$ hydrogen. Growth with $20 \mathrm{~mm}-\mathrm{Na}_{2} \mathrm{~S}_{2} \mathrm{O}_{3}, 20 \mathrm{~mm}-\mathrm{NaNO}_{3}$ and $20 \mathrm{mM}$-sodium bicarbonate was tested in serum bottles under nitrogen gas atmosphere.

Carbonate- and substrate-free cell suspensions for inoculations were prepared by centrifugation $(2600 \mathrm{~g}, 15 \mathrm{~min})$ and washing twice in sterile phosphate-buffered medium. Dry weight was determined after washing cells twice in $20 \mathrm{mM}$-ammonium acetate solution and drying at $80^{\circ} \mathrm{C}$.

Chemical analyses of substrates and products. Acetone and propan-2-ol from culture broth were determined with a Carlo Erba Vega 6000 gas chromatograph with a $2 \mathrm{~m} \times 2 \mathrm{~mm}$ column packed with $60 / 80$ Carbopack $\mathrm{C} / 0.3 \%$ Carbowax $20 \mathrm{M} / 0 \cdot 1 \% \mathrm{H}_{3} \mathrm{PO}_{4}$ (Supelchem, Sulzbach, FRG). The oven temperature was $80^{\circ} \mathrm{C}$, with the detector and injector at $200{ }^{\circ} \mathrm{C}$; the carrier gas was $\mathrm{N}_{2}$ with a flow rate of $45 \mathrm{ml} \mathrm{min}^{-1}$. A $2 \mu \mathrm{l}$ culture sample was injected. The retention time of acetone was $1.3 \mathrm{~min}$ and that of propan-2-ol, $2.0 \mathrm{~min}$. Chromatograms were recorded with a Merck-Hitachi D-2000 integrator.

Nitrite was determined with sulphanilic acid and 1-naphthylamine as described by Procházková (1959). If nitrite was absent, nitrate was determined with chromotropic acid as described by Lange \& Vejdelek (1980).

Analysis of cell compounds. Preparation of DNA and determination of guanine-plus-cytosine content was carried out after Mandel et al. (1970).

PHB was extracted from freeze-dried cells by shaking for $20-24 \mathrm{~h}$ in chloroform $(25 \mathrm{ml}$ chloroform per approx.

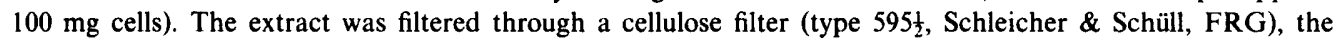
chloroform evaporated, and the dry residue dissolved in 1-4 ml chloroform. The PHB content of this extract was determined after conversion to crotonic acid (Law \& Slepecky, 1961).

Incorporation of ${ }^{14} \mathrm{CO}_{2}$ into PHB was assayed by Schmidt degradation (Simon \& Floss, 1967). PHB was converted to crotonic acid by heating to $100{ }^{\circ} \mathrm{C}$ in $95-97 \% \mathrm{H}_{2} \mathrm{SO}_{4}$ for $15-20 \mathrm{~min}$. The crotonate concentration was adjusted to $1.3-1.4 \mathrm{mM}$ with $95-97 \% \mathrm{H}_{2} \mathrm{SO}_{4}$. A $1 \mathrm{ml}$ volume of this solution was adjusted to $100 \% \mathrm{H}_{2} \mathrm{SO}_{4}$ by addition of $550 \mu \mathrm{l}$ of fuming sulphuric acid $\left(30 \% \mathrm{SO}_{3}\right)$. Then $300 \mu \mathrm{l}$ of this solution (containing about $260 \mathrm{nmol}$ crotonic acid) was transferred into one part of the vessel of a Schmidt degradation apparatus (Fuchs et al., 1980). 
$\mathrm{NaOH}(1 \mathrm{M}, 1 \mathrm{ml})$ was inserted into the other part of the vessel. After freezing at $-70{ }^{\circ} \mathrm{C}, 30 \mathrm{mg}$ sodium azide was put on top of the solidified sulphuric acid solution. The reaction apparatus was closed, heated within 15 min to $70{ }^{\circ} \mathrm{C}$ and kept at this temperature for a further $45 \mathrm{~min}$. After cooling to room temperature, the carbon dioxide released from the crotonate was absorbed in $\mathrm{NaOH}$ over $5 \mathrm{~h}$. For determination of radioactivity in the sulphuric acid fraction, $100 \mu \mathrm{l}$ of the sample was neutralized by dropping into $900 \mu \mathrm{l}$ ice-cold $3.9 \mathrm{M}-\mathrm{NaOH}$. After acidification with formic acid, propionate was detectable in this preparation by gas chromatography without further oxidation.

Radioactivity was determined in a Rackbeta 'Spectral 1219' scintillation counter (LKB, Finland) after addition of $100-200 \mu$ l of neutral to alkaline (max. $1 \mathrm{M}-\mathrm{NaOH}$ ) liquid sample to $20 \mathrm{ml}$ of Quickszint 402 scintillation liquid (Zinsser, Frankfurt, FRG). D.p.m. were calculated after count rate correction for the disturbing effect of sodium azide and the quench effect of alkalinity.

All chemicals (analytical grade) were obtained from Fluka, FRG.

\section{RESULTS}

Enrichment of denitrifying bacteria with ketones

Anoxic non-reduced carbonate-buffered $(30 \mathrm{mM})$ media $(50 \mathrm{ml})$ with sodium nitrate $(50 \mathrm{mM})$ and containing either acetone $(8.2 \mathrm{mM})$, butanone $(6.7 \mathrm{mM})$, pentan-2-one $(5.6 \mathrm{mM})$, pentan-3one $(5.6 \mathrm{~mm})$, hexan-2-one $(4.9 \mathrm{~mm})$, or hexan-3-one $(4.9 \mathrm{~mm})$ as the substrate were each

\section{Table 1. Properties of denitrifying bacteria isolated with various ketones}

All growth tests were carried out under anoxic conditions in carbonate- or phosphate-buffered medium with 10-25 mM-nitrate as electron acceptor, and, if not noted otherwise, $5 \mathrm{~mm}$-substrate. All strains used acetate, propionate, butyrate, valerate, and caproate as substrates and did not grow with pentan-3-one, $\mathrm{D}(+)$-galactose and $\mathrm{L}(-)$-arabinose. + , Good growth; \pm , slow growth; -, no growth.

\begin{tabular}{|c|c|c|c|c|c|}
\hline & & & Strain : & & \\
\hline Character & ActN & BunN* & Pon-2N & Hon-2N & Hon-3N \\
\hline Motility & $+\dagger$ & - & $+\dagger$ & $+\dagger$ & - \\
\hline Catalase & + & + & + & + & ND \\
\hline Oxidase & + & + & + & + & ND \\
\hline Optimal temp. for growth $\left({ }^{\circ} \mathrm{C}\right)$ & 37 & 28 & 28 & 28 & 37 \\
\hline Substrates & & & & & \\
\hline Acetone & + & + & + & - & - \\
\hline Butanone & + & + & + & - & - \\
\hline Pentan-2-one & - & + & + & - & + \\
\hline Hexan-2-one & - & + & - & + & + \\
\hline Hexan-3-one & - & - & - & - & + \\
\hline Heptanoate & - & + & - & + & + \\
\hline Isobutyrate & + & + & + & + & - \\
\hline Isovalerate & + & + & + & + & - \\
\hline Pyruvate & + & + & + & + & - \\
\hline Citrate & - & - & ND & - & - \\
\hline Succinate & + & + & + & + & - \\
\hline Glycerol & - & + & - & - & - \\
\hline$D(+)$-Glucose & - & - & + & - & - \\
\hline$D(-)$-Fructose & - & - & + & - & - \\
\hline$D(+)-X y l o s e$ & ND & \pm & ND & ND & ND \\
\hline Aerobic growth on TS-agar & + & + & + & + & - \\
\hline $\mathrm{G}+\mathrm{C}(\mathrm{mol} \%)$ & $67 \cdot 8$ & $66 \cdot 1$ & ND & $66 \cdot 5$ & $66 \cdot 3$ \\
\hline
\end{tabular}

ND, Not determined.

* BunN was further able to utilize: ethanol, propan-1-ol, propan-2-ol, butan-2-ol, crotonate, lactate, 3hydroxybutyrate, malate, fumarate, aspartate, acetoacetyl ethyl ester ( $3.4 \mathrm{~mm}$, slow growth). The strain did not utilize: 1,2-propanediol, 1,3-propanediol, 1,2-butanediol, 2,3-butanediol, 1,3-butanediol, benzoate (2.5 mm), glycerate, formate (sole carbon and energy source), hydroxyacetone (acetol), acetoacetamide, acetoacetone, acetoin, diacetyl $(1.0 \mathrm{~mm})$.

$\dagger$ Monotrichous monopolar. 
inoculated with $5 \mathrm{ml}$ of activated sludge. After $5 \mathrm{~d}$ incubation at $28^{\circ} \mathrm{C}$, gas formation and increased turbidity was observed in all cultures; in the enrichment culture with hexan-3-one, this happened only after $10 \mathrm{~d}$. Samples $(5 \mathrm{ml})$ of each of these cultures were transferred to $50 \mathrm{ml}$ of fresh medium. After a further 4-10 d, bacteria were isolated from these subcultures by agar shake dilutions in the same medium containing the initial enrichment substrate. Colonies developed within $11 \mathrm{~d}$ and were purified in a second dilution series. Pure cultures of bacteria were obtained with acetone (strain ActN), butanone (strain BunN), pentan-2-one (strain Pon$2 \mathrm{~N}$ ), hexan-2-one (strain Hon-2N) and hexan-3-one (strain Hon-3N). All strains were Gramnegative rods. With pentan-3-one, only a very slow-growing enrichment culture was obtained which was not purified. Table 1 shows the characteristics of the strains isolated. Strain BunN was chosen for further study of acetone degradation because it grew well suspended in liquid culture, whereas the other strains ActN and Pon-2N formed flocs and thus prevented photometric growth measurement.

\section{Characterization of strain BunN}

Cells of strain BunN were straight to slightly curved rods $(1.0 \times 2.2 \mu \mathrm{m})$, Gram-negative, nonmotile, and formed inclusions of PHB (Fig. 1). Formation of a slime capsule was not observed on agar plates or in liquid media. After aerobic growth on TS-agar, catalase and oxidase were detected. No vitamins were needed in the phosphate-buffered mineral salts medium. In ammonium-free media, nitrate was used as the nitrogen source. Molecular $\mathrm{N}_{2}$ was not fixed in ammonium or nitrate-free media supplemented with $\mathrm{Na}_{2} \mathrm{MoO}_{4} \cdot 2 \mathrm{H}_{2} \mathrm{O}$ or $\mathrm{VOSO}_{4} .5 \mathrm{H}_{2} \mathrm{O}$ (each 5 $\mathrm{mg} \mathrm{l}^{-1}$ ). Under these conditions, with 3-hydroxybutyrate as substrate, PHB was formed at a high rate, rendering the cells highly refractile. Chemolithoautotrophic growth with carbon dioxide as the sole carbon source and molecular $\mathrm{H}_{2}$ or thiosulphate as electron donors was not observed. Growth was optimal at $28^{\circ} \mathrm{C}$ (slower growth at $37^{\circ} \mathrm{C}$, no growth at $42^{\circ} \mathrm{C}$ ). Growth occurred at $\mathrm{pH}$ values from 6.2 to 8.7 ; no growth was detectable at $\mathrm{pH} 5$, and $\mathrm{pH}$ values higher than 8.7 were not tested. The guanosine-plus-cytosine content of the DNA was $66.1 \mathrm{~mol} \%( \pm 0.1 \mathrm{~mol} \%)$ as determined by thermal denaturation. Substrates tested as carbon sources are listed in Table 1 . Strain BunN preferentially used ketones and carbonic acids as substrates. Xylose was the only sugar utilized, but growth was extremely slow. No growth occurred with acetol or 1,2propanediol. Acetone, 3-hydroxybutyrate, valerate, and pyruvate were also degraded under aerobic conditions; other substrates were not tested aerobically.

\section{Growth curve and stoichiometry of acetone degradation}

A typical growth curve of strain BunN in phosphate-buffered mineral salts medium with $20 \mathrm{~mm}$-bicarbonate, excess acetone and a limiting amount of nitrate is shown in Fig. 2. Nitrate was converted to nitrogen without measurable release of nitrite. Nitrite was released only in acetone-limited cultures (data not shown). Small amounts of propan-2-ol (0.2-0.3 mM) were formed if nitrate limited growth. The doubling time under optimal growth conditions was $5 \cdot 7-$ $6.0 \mathrm{~h}$ (Figs 2 and 3).

Acetone was degraded completely to $\mathrm{CO}_{2}$ and water (Table 2). The molar growth yield was calculated from total cell dry matter (including PHB) and was $24.8 \mathrm{~g} \mathrm{~mol}^{-1}$ (culture no. 1) and $29.8 \mathrm{~g} \mathrm{~mol}^{-1}$ (culture no. 2).

\section{Dependence of acetone degradation on carbon dioxide}

Growth curves of strain BunN with acetone and increasing amounts of bicarbonate are shown in Fig. 3(a). No growth occurred if the medium lacked bicarbonate. Increasing amounts of bicarbonate led to an increase in growth rates. If bicarbonate was limiting, a tendency to biphasic growth was observed (Fig. $3 a$ ), especially at low bicarbonate concentrations. The initial doubling time was proportional to the reciprocal value of bicarbonate concentration in the medium; an apparent $K_{\mathrm{s}}$ for bicarbonate in batch culture was calculated to be $5.6 \mathrm{~mm}$ (Fig. $3 b$ ). Growth with acetate or 3-hydroxybutyrate did not depend on bicarbonate. The doubling times with these substrates were $4.8 \mathrm{~h}$ and $4.0 \mathrm{~h}$, respectively. 


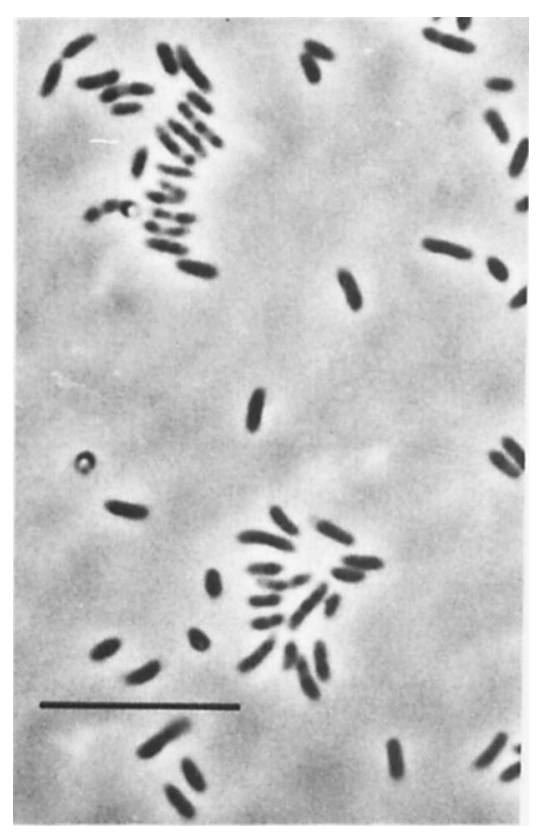

Fig. 1

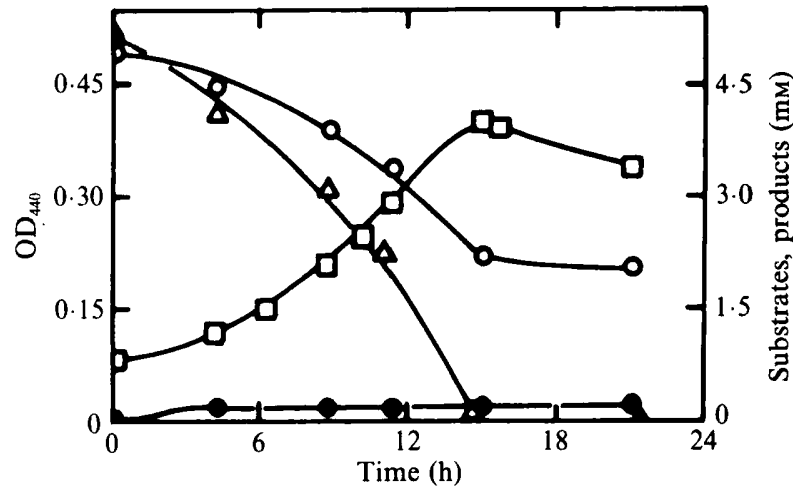

Fig. 2

Fig. 1. Phase contrast photomicrograph of strain BunN. Bar, $10 \mu \mathrm{m}$. PHB appears as dark inclusions due to the preparation techniques applied.

Fig. 2. Growth $\left(\mathrm{OD}_{440}, \square\right)$ of strain BunN with acetone and limiting amounts of nitrate. The experiment was carried out in Hungate tubes $(17.5 \mathrm{ml})$ with $10 \mathrm{ml}$ of phosphate-buffered medium in the presence of $20 \mathrm{~mm}$-sodium bicarbonate. Nitrite was not detectable. $O$, Acetone;, propan-2-ol; $\triangle$, nitrate.

\section{Table 2. Electron recovery after growth of strain BunN with acetone and nitrate}

Two cultures of $945 \mathrm{ml}$ and $980 \mathrm{ml}$ volume with initially $10 \mathrm{~mm}$-acetone and $10.2 \mathrm{mM}( \pm 0.03 \mathrm{~mm})$ sodium nitrate were inoculated with washed cells. The initial turbidity measured in Hungate tubes at $440 \mathrm{~nm}$ was 0.072 (culture no. 1) and 0.080 (culture no. 2). The dry weight calibration value was $21.5 \mathrm{mg}$ $1^{-1}$ at $\mathrm{OD}_{440}=0 \cdot 1$. Cells were harvested in the exponential growth phase.

\begin{tabular}{|c|c|c|c|c|}
\hline & $\mathrm{Cu}$ & Ire no. 1 & Cul & re no. 2 \\
\hline Acetone-consuming reaction* & $\begin{array}{l}\text { Measured } \\
\text { parameter }\end{array}$ & $\begin{array}{l}\text { Stoichiometric } \\
\text { amount of } \\
\text { acetone used } \\
(\mathrm{mmol})\end{array}$ & $\begin{array}{l}\text { Measured } \\
\text { parameter }\end{array}$ & $\begin{array}{l}\text { Stoichiometric } \\
\text { amount of } \\
\text { acetone used } \\
(\mathrm{mmol})\end{array}$ \\
\hline Nitrate consumed' & $9.65 \mathrm{mmol}$ & 3.02 & $8.99 \mathrm{mmol}$ & $2 \cdot 81$ \\
\hline Propan-2-ol formed ${ }^{2}$ & $0.38 \mathrm{mmol}$ & 0.43 & $0.31 \mathrm{mmol}$ & $0 \cdot 35$ \\
\hline $\begin{array}{l}\text { Cell material formed } \\
\text { (not including PHB) }\end{array}$ & $109.9 \mathrm{mg}$ & $1 \cdot 13$ & $93.3 \mathrm{mg}$ & $0: 96$ \\
\hline PHB formed ${ }^{4}$ & $0.8 \mathrm{mg}$ & 0.01 & $41 \cdot 2 \mathrm{mg}$ & 0.54 \\
\hline $\begin{array}{l}\text { Acetone consumption calculated } \\
\text { from formed products } \\
\text { Acetone consumed (measured) }\end{array}$ & & $\begin{array}{l}4 \cdot 59 \\
4 \cdot 90\end{array}$ & & $\begin{array}{l}4 \cdot 66 \\
4 \cdot 87\end{array}$ \\
\hline Electron recovery & & $93 \cdot 7 \%$ & & $95 \cdot 7 \%$ \\
\hline $\begin{array}{l}\text { * Amounts of acetone consumed we } \\
\text { (1) } 5 \mathrm{C}_{3} \mathrm{H}_{6} \mathrm{O}+16 \mathrm{NO}_{3}^{-}+16 \mathrm{H}^{+} \\
\text {(2) } 9 \mathrm{C}_{3} \mathrm{H}_{6} \mathrm{O}+5 \mathrm{H}_{2} \mathrm{O} \\
\text { (3) } 17 \mathrm{C}_{3} \mathrm{H}_{6} \mathrm{O}+13 \mathrm{CO}_{2}+5 \mathrm{H}_{2} \mathrm{O} \\
\text { (4) } 9 \mathrm{C}_{3} \mathrm{H}_{6} \mathrm{O}+5 \mathrm{CO}_{2}\end{array}$ & $\begin{array}{l}\text { ere calculated by } \\
\rightarrow \quad 15 \mathrm{CO}_{2}+8 \\
\rightarrow \quad 8 \mathrm{C}_{3} \mathrm{H}_{8} \mathrm{O}+ \\
\rightarrow \quad 16\left(\mathrm{C}_{4} \mathrm{H}_{7} \mathrm{O}_{3}\right) \\
\rightarrow \quad 8\left(\mathrm{C}_{4} \mathrm{H}_{6} \mathrm{O}_{2}\right)\end{array}$ & $\begin{array}{l}\text { following rea } \\
+23 \mathrm{H}_{2} \mathrm{O} \\
\mathrm{CO}_{2} \\
3 \mathrm{H}_{2} \mathrm{O}\end{array}$ & equations: & \\
\hline
\end{tabular}



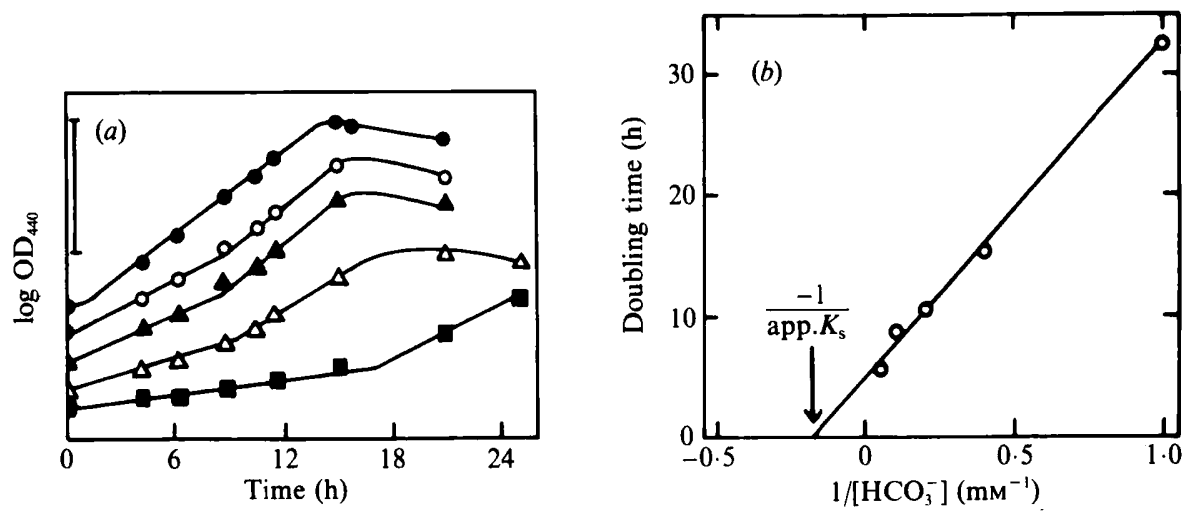

Fig. 3. Dependence of growth of strain BunN with acetone ( $5 \mathrm{~mm})$ and sodium nitrate $(5 \mathrm{~mm})$ on the initial sodium bicarbonate concentration in the medium. Experiments were done in Hungate tubes with $10 \mathrm{ml}$ medium under $\mathrm{N}_{2}\left(\mathrm{CO}_{2}\right.$ free). (a) Semi-logarithmic plot of growth curves $\left(\mathrm{OD}_{440}\right)$ with sodium bicarbonate concentrations of $1.0 \mathrm{mM}(\square), 2.5 \mathrm{mM}(\triangle), 5.0 \mathrm{mM}(\Delta), 10.0 \mathrm{mM}(O)$, and $20.0 \mathrm{~mm}(\mathbf{O})$. The control culture without bicarbonate did not grow (not shown). Bar equals $\Delta \log \mathrm{OD}_{440}=0.05$. Initial OD was $\mathbf{0 . 0 8}$ in all cases. (b) Plot of initial doubling times against the reciprocal of bicarbonate concentration. Initial doubling times were taken from $(a)$.

Table 3. Distribution of ${ }^{14} \mathrm{CO}_{2}$-label in crotonate prepared from $\mathrm{PHB}$ from cells of strain BunN grown with acetone and ${ }^{14} \mathrm{CO}_{2}$-labelled bicarbonate

The experimental conditions are described in the text. Deviations refer to four or five independent measurements of the same preparation.

Preparation before
Schmidt degradation

$264 \mathrm{nmol}$ crotonate

3553 d.p.m. ( $\pm 3 \%$ )
Preparation after Schmidt degradation

$18 \mathrm{nmol}$ crotonate 934 d.p.m. ( $\pm 12 \%)$
Radioactivity released as $\mathrm{CO}_{2}$

2285 d.p.m. ( $\pm 5 \%$ )
Recovery of radioactivity

3219 d.p.m. (90\%)

Under aerobic conditions, acetone degradation also depended on bicarbonate. The $\mathrm{CO}_{2}$ content of air $(0.03 \%)$ was too low for growth with acetone; however, the culture grew well under these conditions if $20 \mathrm{~mm}$-sodium bicarbonate was added in closed culture bottles under air.

\section{Incorporation of ${ }^{14} \mathrm{CO}_{2}$ into $\mathrm{PHB}$}

A dense cell suspension $\left(\mathrm{OD}_{440} 14.9\right.$, corresponding to $80-85 \mathrm{mg}$ dry cells in $27 \mathrm{ml}$ ) was incubated in phosphate-buffered medium containing $15 \mathrm{mM}$-acetone, $50 \mathrm{mM}$-sodium nitrate, 15 mM-sodium bicarbonate with a specific radioactivity of $1.1 \times 10^{8}$ d.p.m. $\mathrm{mmol}^{-1}$, and no ammonium salts. After $4.75 \mathrm{~h}$ of incubation at $28^{\circ} \mathrm{C}$, all acetone was consumed. From $73.5 \mathrm{mg}$ freeze-dried cells, $30.4 \mathrm{mg}$ lipid was extracted containing $28.3 \mathrm{mg}$ PHB (93\%). The specific radioactivity of PHB was $1.54 \pm 0.15 \times 10^{5}$ d.p.m. $(\mathrm{mg} \mathrm{PHB})^{-1}$ [corresponding to $1.33 \pm 0.13$ $\times 10^{7}$ d.p.m. (mmol crotonate) ${ }^{-1}$ ]. Schmidt degradation of crotonate showed that most $(71 \%)$ of the labelled carbon was released as $\mathrm{CO}_{2} ; 29 \%$ of the radioactivity remained in the residual lipid fraction (Table 3).

If 3-hydroxybutyrate was used as substrate in the suspension experiment, the specific radioactivity of the PHB formed was only $6.4 \%$ of that obtained with acetone as substrate.

\section{DISCUSSION}

Enrichment cultures with various ketones in anoxic carbonate-buffered medium led to the isolation of five strains of aerobic, facultatively denitrifying bacteria from activated sludge. Contrary to nearly all ketone-degrading isolates described so far (Levine \& Krampitz, 1952; 
Lukins \& Foster, 1963; Vestal \& Perry, 1969; Taylor et al., 1980; Coleman \& Perry, 1984), all these new isolates were Gram-negative. The only Gram-negative bacterium degrading acetone both aerobically and under denitrifying conditions is Thiosphaera pantotropha (Robertson \& Kuenen, 1983).

The taxonomic affiliation of our new isolates can so far only partially be defined. They all have to be grouped with the Gram-negative aerobic rods in section 4 of Bergey's Manual of Systematic Bacteriology (Krieg, 1984). Strains ActN, Pon-2N and Hon-2N belong to the Pseudomonadaceae, due to their polar monotrichous flagellation and positive catalase and oxidase reaction. Strain Pon-2N grows with sugars as do most members of the Pseudomonadaceae, whereas strains ActN and Hon-2N do not use sugars, which is similar to Pseudomonas alcaligenes and $P$. diminuta (Palleroni, 1984). The non-motile strains Hon-3N and BunN share several properties with the Azotobacteraceae and Rhizobiaceae, as well as with the genera Beijerinckia and Derxia (2-propanol selectively enriches for strains of these genera; Becking, 1984); however, they are unable to fix nitrogen. Failure to grow autotrophically indicates that BunN is not related to Thiosphaera pantotropha (Robertson \& Kuenen, 1983). Further studies will be necessary to allow a definitive taxonomic affiliation of these isolates.

The physiology of nitrate-dependent acetone degradation was studied in detail with strain BunN. It degraded acetone completely to $\mathrm{CO}_{2}$. Small amounts of propan-2-ol were formed in nitrate-limited cultures, possibly by an propan-2-ol dehydrogenase which also enables this strain to use propan-2-ol as a substrate.

$\mathrm{CO}_{2}$ was present at about $30 \mathrm{~mm}$ in the carbonate-buffered medium used for all enrichments, and it turned out that $\mathrm{CO}_{2}$ was essential for good growth with acetone as the substrate. In contrast, growth with acetate or 3-hydroxybutyrate was not $\mathrm{CO}_{2}$-dependent. Anaerobic acetone degradation by our isolate, BunN, involves a primary carboxylation reaction, as also demonstrated by the labelling experiments with ${ }^{14} \mathrm{CO}_{2}$, in which $71 \%$ of the incorporated $\mathrm{CO}_{2}$ was found in the $\mathrm{C}-1$ atom of PHB hydrolysis products, indicating that acetone is first carboxylated to acetoacetate. Twenty-nine percent of the label was not released as $\mathrm{CO}_{2}$ in Schmidt degradation. This finding may be due to two reasons: (1) acetoacetyl-CoA and acetylCoA are in equilibrium with each other (Senior \& Dawes, 1973) and may actively exchange during our incubation experiment thus also labelling the C-3 atom of 3-hydroxybutyrate, and (2) the labelled acetoacetyl-CoA is a precursor of other lipids and is also incorporated into cellular compounds during the incubation time. With these results and the fact that ${ }^{14} \mathrm{CO}_{2}$ was incorporated into PHB only to a small extent with 3-hydroxybutyrate as the substrate it appears, therefore, that strain BunN degrades acetone via carboxylation with $\mathrm{CO}_{2}$ to an acetoacetate residue. Thus an initial hydration as suggested by Rudney (1954) can be excluded; strain BunN is unable to grow with 1,2-propanediol which would be the first intermediate of such a degradation pathway.

Nitrate-dependent acetone oxidation by strain BunN appears to take a similar initial reaction sequence via carboxylation as first described for the phototroph Rhodocyclus gelatinosus (Rhodopseudomonas gelatinosa; Siegel, 1950) and recently for a methanogenic enrichment culture (Platen \& Schink, 1987). Also Thiosphaera pantotropha degrades acetone via carboxylation (Bonnet-Smits et al., 1988). These bacteria were apparently all enriched and isolated in media containing bicarbonate and $\mathrm{CO}_{2}$ at enhanced concentrations ( 30 or $44 \mathrm{~mm}$ ). These concentrations are well suited to satisfy acetone carboxylating enzyme systems with $\mathrm{CO}_{2}$ affinities similar to that of our strain BunN (apparent $K_{\mathrm{s}} 5.6 \mathrm{~mm}$ for bicarbonate). Aerobic acetone degraders, on the other hand, were always enriched in media in which the $\mathrm{CO}_{2}$ content was in equilibrium with air, namely, about $63 \mu \mathrm{M}$ (calculated after Stumm \& Morgan, 1981). It is not surprising, therefore, that all these isolates appear to degrade acetone via an oxygenase reaction rather than via carboxylation. Although oxygenase-catalysed acetone degradation is far less energy-efficient than activation via carboxylation, it may be advantageous under conditions of low substrate supply as this is probably typical of oxic natural habitats.

Part of this study was carried out at the Department of Microbiology of the Philipps-University at Marburg, FRG. The authors are grateful to Professor Dr R. K. Thauer for stimulating discussions. 


\section{REFERENCES}

BeCKING, J.-H. (1984). Genus Beijerinckia. In Bergey's Manual of Systematic Bacteriology, vol. 1, pp. 311321. Edited by N. R. Krieg. Baltimore: Williams \& Wilkins.

Bonnet-Smits, E. M., Robertson, L. A., van DiJken, J. P., Senior, E. \& Kuenen, J. G (1988). Carbon dioxide fixation as the initial step in the metabolism of acetone by Thiosphaera pantotropha. Journal of General Microbiology 134, 2281-2289.

BRINGMANN, G. \& KüHN, R. (1977). Grenzwerte der Schadwirkung wassergefährdender Stoffe gegen Bakterien (Pseudomonas putida) und Grünalgen (Scenedesmus quadricauda) im Zellvermehrungshemmtest. Zeitschrift für Wasser- und Abwasserforschung 10, 87-98.

BringmanN, G. \& KüHN, R. (1978). Grenzwerte der Schadwirkung wassergefährdender Stoffe gegen Blaualgen (Microcystis aeruginosa) und Grünalgen (Scenedesmus quadricauda) im Zellvermehrungshemmtest. Vom Wasser 50, 45-60.

Coleman, J. P. \& Perry, J. J. (1984). Fate of the C, product of propane dissimilation in Mycobacterium vaccae. Journal of Bacteriology 160, 1163-1164.

Davies, R. \& Stephenson, M. (1941). Studies on the acetone-butyl-alcohol fermentation. I. Nutritional and other factors involved in the preparation of active suspensions of Clostridium acetobutylicum (Weizmann). Biochemical Journal 35, 1320-1331.

Fuchs, G., Stupperich, E. \& EDEN, G. (1980). Autotrophic $\mathrm{CO}_{2}$ fixation in Chlorobium limicola. Evidence for the operation of a reductive tricarboxylic acid cycle in growing cells. Archives of Microbiology 128, 64-71.

KRIEG, N. R. (1984). Bergey's Manual of Systematic Bacteriology, vol. 1, pp. 140-407. Baltimore: Williams \& Wilkins.

LANDAU, B. R. \& BRUNENGRABER, H. (1987). The role of acetone in the conversion of carbohydrates. Trends in Biochemical Sciences 12, 113-114.

Lange, B. \& Vejdelek, Z. J. (1980). Photometrische Analyse. Weinheim: Verlag Chemie.

LAW, J. H. \& SLEPECKY, R. A. (1961). Assay of poly- $\beta$ hydroxybutyric acid. Journal of Bacteriology 82, 3336.

LeVINe, S. \& Krampitz, L. O. (1952). The oxidation of acetone by a soil diphteroid. Journal of Bacteriology 64, 645-650.

LUKINS, H. B. \& FosTeR, J. W. (1963). Methylketone metabolism in hydrocarbon utilizing mycobacteria. Journal of Bacteriology 85, 1074-1087.

MaNdel, M., Igambi, L., Bergendahl, J., Dodson, M. R., JR \& Scheltgen. E. (1970). Correlation of melting temperature and cesium chloride buoyant density of bacterial deoxyribonucleic acid. Journal of Bacteriology 101, 330-338.

Mazé, P. (1915). Ferment forménique. Fermentation forménique de l'aceton. Procédé du culture simple du ferment forménique. Comptes Rendus de l'Académie des Sciences, Societé de Biologie 78, 395-405.

NORTHROP, J. H., ASHE, L. H. \& SENIOR, J. K. (1919). Biochemistry of Bacillus acetoethylicum with reference to the formation of acetone. Journal of Biological Chemistry 39, 1-21.

Palleroni, N. J. (1984). Family I. Pseudomonadaceae. In Bergey's Manual of Systemic Bacteriology, vol. 1, pp.. 141-219. Edited by N. R. Krieg. Baltimore: Williams \& Wilkins.

PfENNIG, N. \& TRÜPER, H. G. (1981). Isolation of members of the families Chromatiaceae and Chlorobiaceae. In The Prokaryotes, vol. 1, pp. 279-289. Edited by M. P. Starr, H. Stolp, H. G. Trüper, A. Balows \& H. G. Schlegel. Berlin: Springer-Verlag.

PfEnNIG, N. \& WAGENER, S. (1986). An improved method of preparing wet mounts for photomicrographs of microorganisms. Journal of Microbiological Methods 4, 303-306.

Platen, H. \& Schink, B. (1987). Methanogenic degradation of acetone by an enrichment culture. Archives of Microbiology 149, 136-141.

Plaut, G. W. E. \& LaRdY, H. (1950). Incorporation of the carbons of acetone, formate and carbonate into acetoacetate. Journal of Biological Chemistry 186, 705-715.

ProchÁzKovÁ, L. (1959). Bestimmung der Nitrate im Wasser. Zeitschrift für Analytische Chemie 167, 254260.

Robertson, L. A. \& Kuenen, J. G. (1983). Thiosphaera pantotropha gen. nov. sp. nov., a facultatively anaerobic, facultatively autotrophic sulphur bacterium. Journal of General Microbiology 129, 28472855.

ROTH, L. (1988). Wassergefährdende Stoffe. Teil IV: Stoffinformationen, 7. Ergänzungslieferung, p. 3. Landsberg, FRG: Ecomed Verlagsgesellschaft.

Rudney, H. (1954). Propanediol phosphate as a possible intermediate in the metabolism of acetone. Journal of Biological Chemistry 210, 361-371.

SCHARDINGER, F. (1905). Bacillus macerans, ein Aceton-bildender Rottebacillus. Zentralblatt für Bakteriologie, Parasitenkunde, Infektionskrankheiten und Hygiene, Abteilung II 14, 772-781.

SENIOR, P. J. \& DAwES, E. A. (1973). The regulation of poly- $\beta$-hydroxybutyrate metabolism in Azotobacter beijerinkii. Biochemical Journal 134, 225-238.

SIEGEL, J. M. (1950). The metabolism of acetone by the photosynthetic bacterium Rhodopseudomonas gelatinosa. Journal of Bacteriology 60, 595-606.

Simon, H. \& Floss, H. (1967). Anwendung von Isotopen in der organischen Chemie und Biochemie, vol. 1, pp. 23ff, 50ff. Berlin, Heidelberg \& New York: Springer Verlag.

Stumm, W. \& Morgan, J. J. (1981). Aquatic Chemistry. An Introduction Emphasizing Chemical Equilibria in Natural Waters, 2nd edn. New York: Wiley.

SÜSSMUTH, R., EBERSPÄCHER, J., HAAG, R. \& SPRINGER, W. (1987). Biochemisch-mikrobiologisches Praktikum. Stuttgart: Thieme Verlag.

TAYloR, D. G., TRUdGill, P. W., GRIPPS, R. E. \& Harris, P. R. (1980). The microbial metabolism of acetone. Journal of General Microbiology 118, 159 170.

Vestal, J. R. \& PerRy, J. J. (1969). Divergent metabolic pathways for propane and propionate utilization by a soil isolate. Journal of Bacteriology 99 , 216-221.

WIDDEL, F. (1986). Growth of methanogenic bacteria in pure culture with 2-propanol and other alcohols as hydrogen donors. Applied and Environmental Microbiology 51, 1056-1062.

Widdel, F. \& Pfennig, N. (1981). Studies on 
dissimilatory sulfate-reducing bacteria that decompose fatty acids. I. Isolation of a new sulfate-reducer enriched with acetate from saline environments. Description of Desulfobacter postgatei gen. nov. sp. nov. Archives of Microbiology 129, 395-400.

Widdel, F., Kohring, G. W. \& MAYER, F. (1983)

Studies on dissimilatory sulfate-reducing bacteria that decompose fatty acids. III. Characterization of the filamentous gliding Desulfonema limicola gen. nov. sp. nov., and Desulfonema magnum sp. nov. Archives of Microbiology 134, 286-294.

Widmark, E. M. P. (1920). Studies in the acetone concentration in blood, urine, and alveolar air. II The passage of acetone and aceto-acetic acid into the urine. Biochemical Journal 14, 364-378. 